\title{
PERANAN KEPALA KELUARGA SEBAGAI IMAM DI TENGAH- TENGAH KELUARGA DIMASA PANDEMI COVID-19
}

\author{
Yosefo Gule \\ Universitas Quality Berastagi \\ yosefogule@gmail.com
}

\begin{abstract}
Responding to the increasingly massive and rapid development of the spread of Covid-19, PGI is working together with the government to prevent the spread of Covid-19 by calling on churches to move all church activities, into family activities and worship in their respective homes. The impact of this rule is that the head of the family takes the role of the priest in carrying out worship in the midst of the family. This study aims to determine the role of the head of the family as an imam in the midst of the family during the Covid-19 pandemic. The method of writing in this article is to use a descriptive qualitative study method with a library research approach, reading and comparing a number of references. Conceptually, the role of the head of the family as a priest is very important considering that the head of the family has the role of guarding his family's spirituality before God and the church. As for the main function of the family priest is being able to guide and lead family worship both on Sundays and on weekdays; diligently read the Bible; pray diligently every day; faithfully gives tithe offerings; family worship offerings; be a good advisor and role model for families, especially during the Covid-19 pandemic.
\end{abstract}

Keywords: Priest; Head of Family; Covid-19

\begin{abstract}
ABSTRAK
Menyikapi perkembangan penyebaran Covid-19 yang semakin masif dan cepat maka PGI bersinergi dengan pemerintah untuk menghambat penyebaran Covid-19 dengan menghimbau gereja-gereja untuk memindahkan seluruh aktifitas gereja, menjadi aktifitas dan ibadah keluarga di rumah masing-masing. Dampak aturan tersebut ialah kepala keluarga mengambil peran sebagai imam dalam menjalankan ibadah di tengah-tengah keluarga. Penelitian ini bertujuan untuk mengetahui peranan kepala keluarga sebagai imam di tengah-tengah keluarga dimasa pandemi Covid-19. Metode penulisan pada artikel ini adalah menggunakan metode kajian kualitatif deskriptif dengan pendekatan library research, membaca dan membandingkan sejumlah referensi. Secara konseptual peranan seorang kepala keluarga sebagai imam sangatlah penting mengingat kepala keluarga berperan menjaga kerohanian keluarganya di hadapan Allah dan gereja. Adapun yang menjadi fungsi utama imam keluarga ialah mampu menuntun dan memimpin ibadah keluarga baik pada hari minggu maupun pada hari-hari biasa; rajin membaca Alkitab; tekun berdoa setiap hari; setia memberikan persembahan persepuluhan; persembahan ibadah keluarga; menjadi penasehat dan teladan yang baik bagi keluarga secara khusus dimasa pandemi Covid-19.
\end{abstract}

Kata Kunci: Imam; Kepala Keluarga; Covid-19

\section{PENDAHULUAN}

Pada saat ini seluruh Dunia dan secara khusus bangsa Indonesia sedang dilanda oleh bencana Corona Virus Disease atau sering disebut Covid-19. Virus ini merupakan bagian besar dari Corona virus yang dapat menyerang hewan. Ketika menyerang manusia, Corona virus biasanya menyebabkan penyakit infeksi saluran pernafasan, seperti flu, MERS (Middle East Respiratory Syndrome), dan SARS (Severe Acute Respiratory Syndrome). Covid-19 sendiri merupakan corona virus jenis baru yang ditemukan di Wuhan, Hubei, China pada tahun 2019. Oleh sebab itu, Corona virus jenis baru ini diberi nama Corona Virus Disease - 2019 yang disingkat menjadi Covid-19. Covid-19 sejak ditemukan menyebar secara luas hingga mengakibatkan pandemi global yang berlangsung sampai saat ini. Gejala Covid-19 umumnya berupa demam $38^{\circ} \mathrm{C}$, batuk kering, dan sesak nafas serta dampak paling buruk 
untuk manusia ialah kematian. ${ }^{1}$ Sampai pada tanggal 17 November 2020 dilaporkan terdapat 54.771 .888 kasus terkonfirmasi dari 220 Negara dan yang meninggal 1.324.249. Sedangkan di Indonesia yang Positif 474.455, sembuh 398.636, meninggal 15.393 . $^{2}$ Pandemi global yang terjadi di Indonesia membuat banyak pihak berupaya ikut berperan serta dalam meretas penyebaran Covid-19. Adapun yang menjadi dasarnya ialah:

1) Keputusan Presiden Nomor 9 Tahun 2020 tentang Perubahan atas Keputusan Presiden Nomor 7 Tahun 2020 tentang Gugus Tugas Percepatan Penanganan Corona Virus Disease 2019 (Covid19);

2) Peraturan Pemerintah Nomor 21 Tahun 2020 tentang Pembatasan Sosial Berskala Besar dalam rangka Percepatan Penanganan Corona Virus Disease 2019 (Covid-19); ${ }^{3}$

3) Maklumat Kepala Kepolisian Negara Republik Indonesia Nomor: MAK/2/III/2020 tanggal 19 Maret 2020 Tentang Kepatuhan Masyarakat Terhadap Kebijakan Pemerintah dalam Penanganan Penyebaran Corona Disease 2019 (Covid-19); ${ }^{4}$

4) Permenkes 9 tahun 2020 tentang Pedoman PSBB dalam rangka Percepatan Penanganan Covid$19 ;^{5}$

5) Surat Edaran Bupati Toba Samosir Nomor: 326/Setda/2020 Tentang Himbauan Peningkatan Kewaspadaan Terhadap Corona Virus Disease (Covid-19);

6) Surat Edaran Bupati Toba Nomor: 850/Setda/2020 Tentang Pencegahan Penyebaran Corona Virus Disease (Covid-19) di Kabupaten Toba; ${ }^{7}$

7) Surat Edaran Persekutuan Gereja-Gereja di Indonesia (PGI) Nomor: 230/PGI-XVII/2020 Tentang Hal Memindahkan pelayanan dan ibadah ke ibadah keluarga di rumah masing-masing; ${ }^{8}$

8) Himbauan secara lisan dari Bishop GMI Wilayah 1, Distrik Superintedent, menginstruksikan untuk menjalankan himbauan dari PGI tentang hal memindahkan pelayanan dan ibadah ke ibadah keluarga di rumah masing-masing.

Untuk menyikapi perkembangan penyebaran Covid-19 yang semakin masif dan cepat dan telah menelan banyak korban, maka dengan ini Persekutuan Gereja-Gereja di Indonesia (PGI) bersinergi dengan pemerintah untuk menghambat penyebaran virus Covid-19. MPH-PGI menghimbau gerejagereja untuk memindahkan seluruh aktifitas gereja, termaksud ibadah minggu menjadi aktifitas dan ibadah keluarga di rumah masing-masing. ${ }^{9}$ Mencermati himbauan dari Pemerintah dan PGI tersebut di atas, maka secara khusus Pimpinan Gereja Methodist Indonesia (GMI) Wilayah 1 menindak lanjuti himbauan tersebut kepada para Distrik Superintendent (DS) dan dilanjutkan kepada para Pendeta. Untuk merespon kebijakan pemerintah dan gereja tersebut, maka dalam hal ini GMI Parsambilan mengambil kebijakan menghimbau seluruh jemaat untuk beribadah di rumah masing-masing sejak Maret 2020 sampai batas yang tidak ditentukan. Pimpinan jemaat dan para majelis menyiapkan tata ibadah keluarga

\footnotetext{
${ }^{1}$ Adib Rifqi Setiawan, "Lembar Kegiatan Literasi Saintifik Untuk Pembelajaran Jarak Jauh Topik Penyakit Coronavirus 2019 (COVID-19)," Edukatif: Jurnal Ilmu Pendidikan 2, no. 1 (2020): 28-37, https://doi.org/10.31004/edukatif.v2i1.80.

${ }^{2}$ Satuan Tugas Penanganan COVID-19: https://covid19.go.id/, dikutip pada tanggal: 18 November 2020.

${ }^{3}$ Satuan Tugas Penanganan COVID-19: https://covid19.go.id/, dikutip pada tanggal: 21 Mei 2020.

${ }^{4}$ Maklumat Kepala Kepolisian Negara Republik Indonesia Nomor: MAK/2/III/2020 tanggal 19 Maret 2020.

${ }^{5}$ Permenkes 9 tahun 2020 tentang Pedoman PSBB dalam rangka Percepatan Penanganan Covid-19.

${ }^{6}$ Surat Edaran Bupati Toba Samosir Nomor: 326/Setda/2020 Tentang Himbauan Peningkatan Kewaspadaan Terhadap Corona Virus Disease (Covid-19).

${ }^{7}$ Surat Edaran Bupati Toba Nomor: 850/Setda/2020 Tentang Pencegahan Penyebaran Corona Virus Disease (Covid-19) di Kabupaten Toba.

${ }^{8}$ Surat Edaran Persekutuan Gereja-Gereja di Indonesia (PGI) Nomor: 230/PGI-XVII/2020.

${ }^{9}$ Surat Edaran Persekutuan Gereja-Gereja di Indonesia (PGI) Nomor: 230/PGI-XVII/2020 Tentang Hal Memindahkan Pelayanan dan Ibadah ke Ibadah Keluarga di Rumah Masing-masing.
} 
dan di bagikan kepada setiap anggota keluarga jemaat GMI Parsambilan yang nantinya digunakan oleh masing-masing keluarga sebagai panduan ibadah di rumah masing-masing pada hari minggu, serta bacaan Alkitab satu minggu kedepannya. Dengan situasi ini, maka kepala keluarga tampil sebagai imam di tengah-tengah keluarga untuk menjalankan ibadah minggu di rumah masing-masing, sebagai pengajar spiritualitas iman Kristen, pengayom bagi istri dan anak-anaknya, serta mampu menyikapi dampak pandemi Covid-19 ini dengan baik.

Di dalam Alkitab ditegaskan bahwa Allah memerintahkan kepada Musa untuk menyampaikan kepada bangsa Israel bahwa orang tua harus menjadi imam untuk mengajarkan pengalaman-pengalaman mereka bersama Tuhan dan mengajarkan ketetapan-ketetapan Tuhan terhadap anak-anaknya, secara berulang-ulang dalam setiap kesempatan, baik ketika di rumah atau dalam perjalanan, baik saat berbaring atau bangun. Bahkan perintah-perintah Tuhan tidak hanya ditempel di dinding rumah atau pintu gerbang tetapi juga pada tubuh anaknya sendiri (Ulangan 6:6-9). Kepala keluarga yang berperan sebagai imam harus mampu membangun persekutuan dengan keluarga dengan saling melibatkan semua orang dalam perencanaan dan pencapaian tujuan keluarga, saling mendukung, serta menunjukkan kepercayaan dan kesetiaan. Secara umum didalam gereja yang menjadi seorang imam bagi seluruh warga jemaatnya ialah Pendeta, sedangkan di masa pandemi Covid-19 ini, mau tidak mau kepala keluargalah yang mengambil peran sebagai imam. Oleh sebab itu, kepala keluarga sudah sepatutnya menjadi teladan secara karakter maupun rohani bagi keluarganya. Seorang kepala keluarga berperan membantu anggota keluarganya tumbuh dalam hubungan mereka dengan Tuhan. Dia memberikan dukungan baik secara psikis dan rohani kepada istri maupun anak-anaknya. Dalam kitab 1 Korintus 11:3 "Tetapi aku mau, supaya kamu mengetahui hal ini, yaitu Kepala dari tiap-tiap laki-laki ialah Kristus, kepala dari perempuan ialah laki-laki dan kepala dari Kristus ialah Allah”. Selanjutnya dalam kitab Kolose 3:20 "Hai anak-anak, taatilah orangtuamu di dalam segala hal, karena itulah yang indah di dalam Tuhan". ${ }^{10}$

Melalui uraian di atas Allah telah mengatur keluarga menurut suatu prinsip yakni harus ada seorang kepala keluarga sebagai imam untuk menjalankan kegiatan rohani di dalam keluarga, seperti ibadah keluarga, membaca Firman Tuhan bersama, berdoa bersama, dan bimbingan pengajaran iman kepada istri dan anak-anak serta memberikan apa yang menjadi tanggung-jawab bagi gereja.

Dalam disiplin GMI telah ditetapkan apa-apa saja yang menjadi tugas dan tanggung jawab anggota jemaat salah satunya adalah melaksanakan kebaktian keluarga. Hal ini menginstruksikan bahwa selain kebaktian umum di gereja setiap hari minggu, kepala keluarga juga harus berperan sebagai imam di tengah-tengah keluarganya untuk melaksanakan kebaktian atau ibadah keluarga. Selain itu seorang kepala keluarga mampu menuntun keluarganya untuk rajin membaca Firman Tuhan, rajin dan tekun berdoa setiap hari. Setia mempersembahkan persepuluhan setiap bulan dan setia memberikan persembahan lainnya.

Berdasarkan latar belakang masalah di atas, maka tulisan ini bertujuan untuk mengetahui dan mendeskripsikan apa-apa saja yang menjadi peranan kepala keluarga sebagai imam di tengah-tengah keluarga di masa pandemi Covid-19 ini.

\section{METODE}

Metode penelitian pada penulisan artikel ini adalah menggunakan metode kajian kualitatif deskriptif dengan pendekatan library research, membaca dan membandingkan sejumlah referensi ${ }^{11}$

\footnotetext{
${ }^{10}$ Agung Gunawan, “Kasih Fondasi Keluarga Yang Sehat,” Jurnal Theologia Aletheia 21, no. 17 (2019): 59-80, http://sttaletheia.ac.id/e-journal/index.php/solagratia/article/view/95/91.

${ }^{11}$ Mariani Harmadi and Ruat Diana, "Tinjauan Psiko-Teologi Terhadap Fenomena Kekerasan Dalam Pacaran Pada Remaja," Evangelikal: Jurnal Teologi Injili dan Pembinaan Warga Jemaat 4, no. 1 (2020): 92-102, https://doi.org/10.46445/ejti.v4i1.225.
} 
yang berhubungan dengan peranan kepala keluarga sebagai imam di tengah-tengah keluarga di masa pandemi Covid-19. Kegiatan penelitian dilakukan dengan cara menelaah dan menganalisis berbagai sumber seperti jurnal, buku, artikel prosiding, atau informasi lain yang berhubungan dengan judul penelitian. Hasil analisis dari proses tersebut di sajikan secara deskriptif (lebih jelasnya proses penelitian dalam tulisan ini dapat dilihat pada gambar 1). Berdasarkan latar belakang masalah yang telah penulis uraikan di bagian pendahuluan, maka tulisan ini bertujuan untuk mengetahui peranan kepala keluarga sebagai imam di tengah-tengah keluarga di masa pandemi Covid-19, dengan mengajukan beberapa pertanyaan sebagai acuan dalam penelitian ini. Apa itu keluarga dan imam dalam perspektif Kristen; bagaimana peranan seorang kepala keluarga sebagai imam di tengah-tengah keluarga? Tujuan penelitian ini adalah untuk "mengetahui peranan kepala keluarga sebagai imam di tengah-tengah keluarga di masa pandemi Covid-19 di jemaat GMI Parsambilan, Kecamatan Silaen, Kabupaten Tobasa". Penelitian ini diharapkan memberikan manfaat kepada para pimpinan gereja dan warga jemaat gereja.

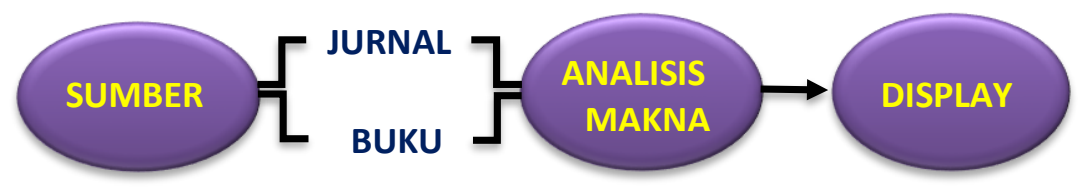

Gambar 1. Proses Penelitian

\section{HASIL DAN PEMBAHASAN}

\section{Dampak Pandemi Covid-19 Terhadap Kehidupan Keluarga}

Dampak Covid-19 yang sedang berlangsung sekarang ini membawa dampak luas dalam kehidupan masyarakat dan secara khusus keluarga Kristen, baik dari segi sosial, ekonomi, kerohanian termasuk di dalamnya bagaimana keluarga Kristen tetap mampu menjaga kualitas kerohaniannya di masa pandemi Covid-19 ini. Dari segi sosial kehidupan masyarakat tidak seperti biasanya, harus stay at home dan work from home, setiap orang harus menjaga jarak ketika berpergian, dan tidak boleh berkerumun atau kumpul-kumpul. ${ }^{12}$

Dari segi ekonomi keuangan keluarga semakin terbatas, akibat stay at home dan work from home sementara kebutuhan akan makanan, dan kebutuhan anak-anak semakin tinggi. Terutama yang pada dasarnya menggantungkan hidupnya pada pekerjaan berjualan di pajak, tukang becak, buruh harian lepas, buruh pabrik dll, akan langsung memberikan dampak negatif atas pendapatan mereka, sehingga masyarakat tidak bisa memenuhi kehidupan mereka sehari-hari, khususnya yang memiliki sanak keluarga kebingungan dalam upaya memenuhi kebutuhan hidup setiap hari seperti, biaya makan untuk setiap harinya, untuk membayar cicilan motor, uang sekolah anak-anak dan berbagai tanggungan hidup lainnya. ${ }^{13}$

Dari segi kerohanian dampak kebijakan pemerintah yang mewajibkan warga jemaat beribadah di rumah membuat sebagian warga jemaat tidak siap menghadapi situasi ini, dengan situasi ini mau tidak mau kepala keluarga harus tampil sebagai imam di tengah-tengah keluarga untuk melaksanakan ibadah bersama. Namun dalam kenyataannya banyak jemaat tidak melaksanakan ibadah di rumah pada hari minggu maupun pada hari-hari biasa. Kepala keluarga kurang berperan sebagai imam di tengah-tengah

\footnotetext{
12 Meilita Ering, “Gereja Rumah di Masa Pandemi Covid-19: Manajemen Resiko dan Mitigasi Bencana Non Alam," Jurnal Sosiologi Agama 1, no. $1 \quad$ (2020): 1-14, http://ejournal-iaknmanado.ac.id/index.php/putewaya/article/view/214/202.

${ }^{13}$ Albet Saragih and Johanes Waldes Hasugian, "Model Asuhan Keluarga Kristen di Masa Pandemi Covid-19," Jurtnal Teruna Bhakti 3, no. 1 (2020): 1-11, http://stakterunabhakti.ac.id/ejournal/index.php/teruna/article/view/56.
} 
keluarga. Seharusnya setiap kepala keluarga harus menjalankan tugas dan tanggung jawabnya sebagai warga jemaat gereja yang baik yaitu salah satunya adalah melaksanakan kebaktian keluarga. ${ }^{14}$ Dengan situasi Covid-19 ini mau tidak mau maka kepala keluarga harus tampil sebagai imam di tengah-tengah keluarga untuk menjalankan ibadah minggu di rumah masing-masing bahkan pada hari-hari biasa, sebagai pengajar spiritualitas iman Kristen, serta mampu menyikapi dampak pandemi Covid-19 ini dengan baik dan bijaksana.

\section{Pengertian Keluarga dalam Perspektif Kristen}

Menurut Sihombing pengertian keluarga dapat diartikan sebagai seorang suami-istri yang hidup dalam satu rumah dengan seorang anak sebagai hasil perkawinan mereka. ${ }^{15}$ Kesaksian Alkitab memperlihatkan bahwa keluarga dibentuk akibat penyatuan antara seorang laki-laki dengan seorang perempuan yang meninggalkan ayah-ibunya, maka keduanya menjadi satu daging dan mereka dipersatukan Allah dan tidak boleh diceraikan oleh manusia (Matius 19: 5-6).

Sijabat berpendapat bahwa keluarga adalah hasil rencana pembentukan Allah (Kejadian 2:18; Mazmur 127:1-2). Sebuah keluarga dalam hal ini menggambarkan hubungan Kristus dengan GerejaNya (Efesus 5:22-23). Di dalam keluarga ada kesatuan dan persekutuan spiritual. Tuhan mendesain keluarga juga untuk menyatakan rupa dan gambar-Nya (Kejadian 1:26-27). Keluarga harus menjadi saluran kasih atau berkat Allah bagi sesamanya dan menjadi wadah bagi transmisi nilai-nilai luhur ajaran kekristenan. ${ }^{16}$

Sedangkan Homrighausen berpendapat bahwa Keluarga Kristen ialah pemberian dari Tuhan sang pemberi kehidupan. Di dalam Kitab Efesus 6:1-4 memperlihatkan bahwa keluarga Kristen harus taat kepada Yesus Kristus dalam kehidupan, baik ayah-ibu dan anak-anaknya. Keluarga Kristen adalah hasil rencana pembentukan Allah yang tidak ternilai harganya yang berperan sebagai alat untuk menggambarkan hubungan Kristus dengan Gereja-Nya dan menerima, mengimani Tuhan sebagai tempat bernaung mereka serta menjadikannya sebagai fondasi dalam keluarga. Untuk segala tindakan yang dilakukan dalam keluarga Kristen harus berpatokan pada pengajaran Tuhan Yesus dimana kasih menjadi pengikat antara yang satu dengan yang lain. ${ }^{17}$

Menurut Thompson keluarga adalah sebagai tempat bernaungnya yang kudus, artinya suatu tempat penerimaan, pembinaan dan pertumbuhan yang memberdayakan anggota-anggota keluarga untuk berperan serta dalam tindakan kasih dan penyelamatan Allah yang berkelanjutan. ${ }^{18}$ Senada dengan pendapat di atas, Kristianto mengklasifikasikan pengertian keluarga ke dalam empat bagian yaitu: (1) keluarga adalah tempat perkembangan, menyangkut: pertumbuhan tubuh, hubungan sosial, akal budi dan kasih serta rohani. Manusia diciptakan seturut gambar-rupa Allah sehingga manusia mempunyai potensi untuk bertumbuh kepada kehendak Allah. Keluarga ialah tempat untuk memberi perhatian, komitmen, teladan, kasih dan lingkungan keluarga yang kondusif untuk bertumbuh secara produktif ke arah Kristus Yesus; 2) keluarga adalah pusat pengembangan semua kreatifitas keluarga. Didalam keluarga landasan kehidupan seorang anak dibentuk; (3) keluarga adalah tempat yang baik untuk bernaung saat ada badai persoalan kehidupan. Dalam konteks ini keluarga akan tampil sebagai

\footnotetext{
${ }^{14}$ Abraham Tefbana and Djoys Anneke Rantung, "Perspektif Pendidikan Agama Kristen Terhadap Teologi Kebencanaan dan Peran Gereja Dalam Menghadapi Pendemic Covid 19,” Jurnal Luxnos 6, no. 1 (2020): 72-88, https://doi.org/10.47304/j1.v6i1.32.

15 Riana Udurman Sihombing and Rahel Rati Sarungallo, "Peranan Orang Tua Dalam Mendewasakan Iman Keluarga Kristen,” Journal Kerusso 4, no. 1 (2019): 34-41, https://doi.org/10.33856/kerusso.v4i1.104.

${ }^{16}$ Binsen S. Sijabat, Membesarkan Anak Dengan Kreatif, Panduan Menanamkan Iman \& moral Kepada Anak Sejak Dini (Yogyakarta: Andi, 2013),138.

${ }^{17}$ E.G dan Enklaar Homrighausen, Pendidikan Agama Kristen (Jakarta: BPK-Gunung Mulia, 2011), 128.

${ }^{18}$ Marjorie L. Thompson, Keluarga Sebagai Pusat Pembentukan: Sebuah Visi Tentang Peranan Keluarga Dalam Pembentukan Rohani (Jakarta: BPK-Gunung Mulia, 2012), 55.
} 
pemberi perhatian, kasih sayang dan perlindungan; (4) keluarga merupakan tempat untuk mentransfer nilai-nilai, laboratorium hidup bagi setiap anggota keluarga dan saling belajar hal yang baik. ${ }^{19}$

Singkatnya keluarga adalah hasil rencana pembentukan Allah. Di dalam keluarga terdapat ayahibu beserta anak-anak. Keluarga bukan saja terpanggil untuk tempat pengembangbiakan anak. Akan tetapi, keluarga menjadi saluran kasih atau berkat bagi sesamanya dan menjadi wadah bagi transmisi nilai-nilai luhur ajaran kekristenan dan sebagai tempat awal permulaan penanaman nilai-nilai ajaran Kekristenan. ${ }^{20}$

\section{Imam Dalam Perspektif Kristen}

Dalam KBBI pengertian imam ialah seorang pemimpin ibadah. ${ }^{21}$ Dalam konteks agama Kristen, imam ialah orang yang mempunyai tugas dan peranan yang khas yaitu sebagai pemimpin ibadah dalam gereja. Istilah imam dapat disinonimkan dengan kata padre, kepala, pemimpin, pastor, pendeta. ${ }^{22}$ Dalam Alkitab, imam berarti pengantara manusia dengan Tuhan. Sebagai pengantara, imam berfungsi untuk menyampaikan permohonan, keluhan umat manusia. ${ }^{23}$

Kata imam dapat diartikan sebagai priests yaitu seorang anggota keluarga yang dikhususkan untuk mempersembahkan kurban dan menjadi pengantara antara Allah dan manusia secara berkualitas dalam konteks kecil (keluarga), lalu berkembang dalam konteks luas (masyarakat/umat Allah) seperti Imam Lewi dalam PL (Keluaran 28:1; 32:25-29; Imamat. 8:1-9:24), atau Raja imam Melkisedek (Kejadian 14:18-20). ${ }^{24}$ Sedangkan Yesus disebut sebagai Imam Besar Agung (Ibrani 4:14-5:10) Sebagai sang Pengantara antara Allah dan manusia (1 Tim. 2:5). ${ }^{25}$

Dalam tradisi masyarakat Israel, imam adalah orang-orang tertentu yang bertugas di dalam bait Allah di Yerusalem. Mereka adalah keturunan suku Lewi. Pada dasarnya seorang imam bertugas sebagai perantara manusia dengan Allah, berdoa untuk kepentingan bangsa Israel, maupun imam secara pribadi dalam keluarga masing-masing. Mereka mempersembahkan korban bakaran dan lain-lain dalam Bait Allah dan atas nama Allah menyampaikan berkat, dan pengampunan atas dosa-dosa yang diperbuat.

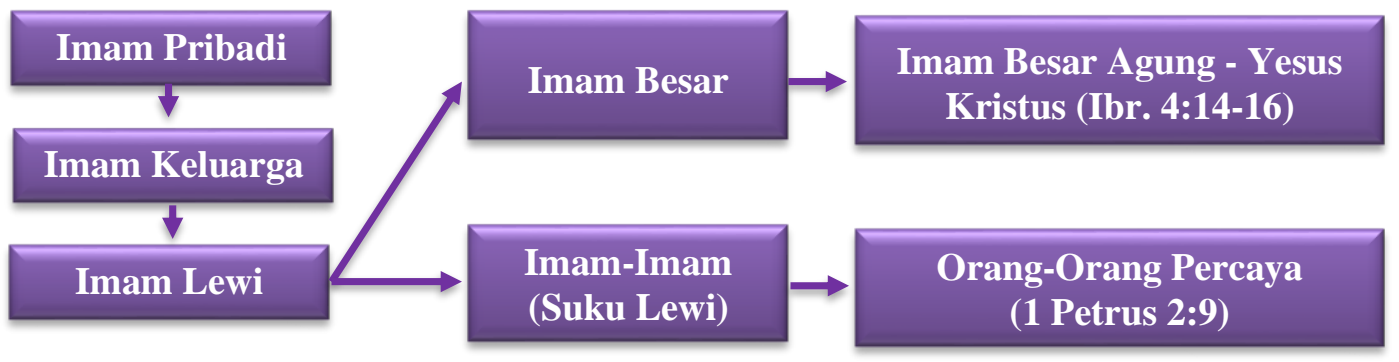

Gambar 2. Skema Keimaman dalam Alkitab

Para imam dibagi menjadi beberapa kelompok, dan kelompok-kelompok itu bertugas secara bergiliran

\footnotetext{
${ }^{19}$ Paulus Lilik Kristianto, Prinsip \& Praktik Pendidikan Agama Kristen: Penuntun Bagi Mahasiswa Teologi \& PAK, Pelayanan Gereja, Guru Agama, dan Keluarga Kristen (Yogyakarta: Andi, 2012), 139-140.

${ }^{20}$ Hardi Budiyana, "Perspektif Alkitab Terhadap Keluarga Kristen," Regula Fidei 3, no. 2 (2018): 137-45, http://christianeducation.id/e-journal/index.php/regulafidei/article/view/25/24.

${ }^{21}$ W.J.S. Poerwadarminta, Kamus Umum Bahasa Indonesia (Jakarta: Balai Pustaka, 2009), 375.

${ }^{22}$ H. Kridalaksana, Kamus Sinonim Bahasa Indonesia (Nusa Indah: Ende, 2009), 132.

${ }^{23}$ A. Baker, Ajaran Iman Katolik (Yogyakarta: Kanisius, 2008), 75.

${ }^{24}$ Paulus Kunto Baskoro, “Konsep Imam dan Jabatan Imam Pada Masa Intertestamental,” Jurnal Teologi Berita Hidup 3, no. 1 (2020): 81-95, https://www.e-journal.sttberitahidup.ac.id/index.php/jbh/article/view/50/49.

${ }^{25}$ SJ. Gerald O’collins, SJ \& Edward G. Farrugia, Kamus Teologi (Yogyakarta: Kanisius, 2009), 112-113.
} 
menurut ketentuan yang berlaku. Pada Gambar 2. diperlihatkan sekema perkembangan posisi seorang imam. ${ }^{26}$

Dari uraian di atas tentang pengertian imam dalam perspektif Kristen dapat disimpulkan bahwa dari sejak awal Allah telah menetapkan seorang imam yang menjadi perantara kepada Allah. Seorang imam pada awalnya bertindak secara pribadi kepada Allah dalam menyampaikan permohonannya. Sedangkan dalam konteks keluarga, seorang kepala keluargalah yang akan menjadi pengantara bagi Allah. Sedangkan dalam ranah gereja atau umat seorang pemimpin itu adalah Imam Lewi yang setara dengan seorang Pendeta saat ini. Namun Imam yang Agung dan utama adalah Yesus Kristus. ${ }^{27}$ Sebagai imam di tengah-tengah keluarga, imam berfungsi untuk menyampaikan permohonan kepada Allah lewat persekutuan ibadah, penyampai Firman Tuhan di tengah-tengah keluarga, penasehat dan pemberi teladan yang baik serta mampu memberikan kewajibannya kepada gereja-Nya atas karya Allah didalam keluarga. Fungsi utama imam di atas senada dengan yang dikemukakan oleh Ismail, hanya saja seorang imam dalam konteks keluarga tidak bisa menjalankan sakramen-sakramen karena tugas ini hanya bisa dijalankan oleh seorang Pendeta. ${ }^{28}$

\section{Peranan Kepala Keluarga Sebagai Imam di Tengah-Tengah Keluarga}

Allah telah membentuk tiga lembaga manusia yang didalamnya ada kepala yang berperan sebagai imam yaitu: Keluarga, Gereja dan Pemerintah. Masing-masing lembaga itu memiliki maksudmaksudnya tersendiri, namun ketiganya saling berkaitan. ${ }^{29}$ Namun dalam tulisan ini akan memfokuskan pada lembaga keluarga. Kepala keluarga adalah orang yang bertanggung jawab terhadap suatu keluarga (biasanya kaum bapak). Kepala keluarga yang utama adalah laki-laki (suami). Jika suami sudah tidak ada atau meninggal dunia, maka tugas kepala keluarga digantikan oleh seorang ibu. Suami merupakan kepala keluarga yang bertanggung jawab atas keseluruhan anggota keluarga. ${ }^{30}$ Seorang kepala keluarga berkaitan dengan segala sesuatu yang tidak hanya mengurusi hal-hal yang berbentuk fisik atau nyata, melainkan kepala keluarga yang mengatur visi dan misi keluarga untuk membentuk suatu keluarga yang baik sesuai kehendak Allah. Pada dasarnya kepala keluarga berperan untuk melindungi, menghidupi, dan mendidik anak-anak agar kelak dapat hidup layak dan mandiri. ${ }^{31}$

Senada dengan pendapat di atas Claartje Pattinama berpendapat bahwa peran kepala keluarga dalam sebuah keluarga bukan saja dalam upaya memenuhi kebutuhan ekonomi dalam keluarga, tapi lebih dari itu, tentu saja untuk nantinya dapat melihat perkembangan dan pertumbuhan anaknya tapi juga bertanggung jawab pada pemberian bimbingan tentang nilai-nilai moral, keagamaan, dan kedisiplinan dalam mengasuh serta mengendalikan anak untuk nantinya bertumbuh sebagai individu yang matang dalam berpikir dan bertindak di kehidupan sosial masyarakatnya. ${ }^{32}$

Dalam kitab Perjanjian Lama memberikan gambaran bahwa orang tua adalah sebagai kepala keluarga yang bertanggung jawab atas kerohanian dan moral dari anak-anak yang telah dipercayakan

\footnotetext{
${ }^{26}$ M.K. Sembiring, Pedoman Penafsiran Alkitab Injil Lukas (Jakarta: Lembaga Alkita Indonesia dan Yayasan Karunia Bakti Budaya Idonesia, 2005), 9.

${ }^{27}$ Ernest Mariyanto, Kamus Liturgi Sederhana (Yogyakarta: Kanisius, 2008), 77.

${ }^{28}$ Andar Ismail, Awam dan Pendeta Mitra Membina Gereja (Jakarta: BPK-Gunung Mulia, 2009), 5.

${ }^{29}$ Ronald W. Leigh, Melayani Dengan Evektif: 34 Prinsip Pelayanan Bagi Pendeta dan Kaum Awam (Jakarta: BPK-Gunung Mulia, 2007), 107.

${ }^{30}$ Bangun Munthe, "Peranan Orangtua Terhadap Peningkatan Kesejahteraan Keluarga Untuk Mewujudkan Tanggungjawab Dalam Keluarga, Gereja dan Masyarakat,” Jurnal Agape 1, no. 1 (2018): 62-91, http://repository.uhn.ac.id/handle/123456789/1490.

${ }^{31}$ Nandari Prastica Wagiu, "Implementasi Peran Orang Tua Menurut Ulangan 6:4-9 Dalam Pendidikan Agama Kristen Keluarga di Gereja Masehi Injili di Minahasa Jemaat Imanuel Aertembaga Bitung," Jurnal Shanan 4, no. 2 (2020): 128-61, http://ejournal.uki.ac.id/index.php/shan/article/view/1972.

32 Claartje Pattinama, "Peranan Orang Tua Terhadap Perkembangan Pendidikan Anak Dalam Keluarga Kristen," Jurnal Ilmiah Wahana Pendidikan 6, no. 3 (2020): 199-205, https://doi.org/10.5281/zenodo.3951005.
} 
Tuhan. Bagi bangsa Israel, seorang kepala keluarga memiliki peran yang sama dengan nabi dan imam, yakni menyampaikan dan meneruskan berita karya keselamatan Allah kepada anak-anak dan istrinya. Sedangkan dalam kitab Perjanjian Baru memperlihatkan bahwa seorang ayah atau suami berkedudukan atau menjabat sebagai kepala keluarga (Ef. 5:23), dan seorang istri sebagai penjaga keserasian dan keseimbangan hubungan keluarga. ${ }^{33}$ Selain itu seorang kepala keluarga ialah seorang imam di tengahtengah keluarganya (Kel. $19: 6$, Hak. $17: 7,10 \mathrm{a}$ ), sebagai sang pemimpin bagi keluarganya (1 Tim. 3 : 4-5; Ef. $5: 23 a$ ), dan sebagai seorang pencari nafkah bagi anak-anak dan istrinya (Kej. $2: 15,3: 19){ }^{34}$

Sekaitan dengan uraian di atas seorang kepala keluarga juga memiliki fungsi dan peran sebagai imam di tengah-tengah keluarganya, yaitu: Pertama, kepala keluarga sebagai penuntun dan pemimpin ibadah di tengah-tengah keluarga. Pengertian kata ibadah dalam kitab Perjanjian Lama (PL) dalam

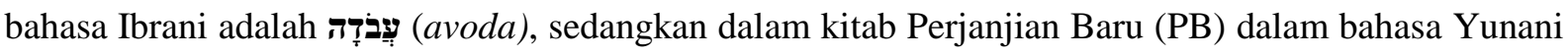
adalah $\lambda \alpha \tau \rho \varepsilon ı \alpha$ (latreian) yang memiliki makna sebuah tindakan dan sebuah sikap dalam rangka mempersembahkan ibadat kepada Allah. Dalam upacara atau ibadah gerejawi, tersusunlah sebuah tata ibadah yang lazim disebut sebagai liturgi. Liturgi adalah tata ibadah dan bahkan ibadah itu sendiri. Tata ibadah berkaitan erat dengan ibadah karena tata ibadah itu merupakan pewujudan dari ibadah itu sendiri. Singkatnya ibadah secara eksistensial itu ada terlebih dahulu, lalu kemudian diwujud nyatakan dalam tata cara tertentu dan dalam keteraturan tertentu. ${ }^{35}$

Oleh sebab itu seorang kepala keluarga yang berperan sebagai imam harus mampu memahami tentang tata ibadah atau liturgi ibadah yang dapat diaplikasikan dalam ibadah keluarga. Dalam hal ini peranan kepala keluarga sebagai imam ialah bagaimana ia mampu mempersiapkan anggota keluarganya untuk melaksanakan ibadah dan memandunya secara baik. ${ }^{36}$ Tujuannya adalah sebagai penghormatan kepada Allah akan kasih dan anugerah-Nya kepada keluarga. Ibadah merupakan wujud ketundukkan manusia terhadap sang pencipta-Nya. Di dalam ibadah terkandung unsur pujian, doa, persembahan / ucapan sukur serta perenungan dan pembacaan Alkitab atau perenungan Firman Allah yang di pandu oleh kepala keluarga. Untuk memahami esensi pemahaman ibadah di gereja dan keluarga, dalam hal ini penulis menggunakan pendekatan dari paham White yang mengklasifikasikan antara ibadah umum dan ibadah pribadi atau keluarga. Dalam ibadah umum merupakan ibadah yang di persembahkan jemaat yang berkumpul bersama-sama dalam konteks gereja. Sedangkan ibadah secara perkeluarga ialah ibadah yang di persembahkan keluarga yang berkumpul bersama-sama dalam satu keluarga. Baik ibadah umum dan pribadi atau perkeluarga keduanya sepenuhnya adalah sah karena keduanya saling mengambil bagian dalam ibadah dari persekutuan tubuh Kristus yang universal. ${ }^{37}$

Kedua, kepala keluarga sebagai pengajar firman Tuhan kepada keluarga. Seorang kepala keluarga harus mampu menyampaikan dan mengajarkan Firman Allah di dalam keluarganya. Orang beriman harus dapat menjelaskan arti imannya baik secara kontekstual maupun dalam pengalaman hidup. Mengajarkan Firman Allah ialah tugas utama yang sangat penting dan tidak boleh diabaikan oleh para orang tua Yahudi (Ulangan 6:6-9), para orang tua Yahudi selalu mengajar anak-anak mereka serta seluruh anggota keluarga akan kebenaran Firman Allah dalam setiap waktu dan kesempatan. Pengajaran

\footnotetext{
${ }^{33}$ Andriaan MF. Wakkary, "Peran Keluarga Kristen Bagi Pendidikan Remaja," Rhema: Jurnal Teologi Biblika Dan Praktika 4, no. 1 (2018): 4-8, https://e-journal.stt-yestoya.ac.id/index.php/rhema/article/view/32/21.

${ }^{34}$ Magdalena G.K. Tindagi, "Indikator Penanaman Nilai-Nilai Pak Dalam Keluarga Bagi Perbinaan Iman Anak Remaja di Zaman Now," Missio Ecclesiae 6, no. 1 (2017): 17-31, https://jurnal.i3batu.ac.id/index.php/me/article/view/67.

35 Jarot Kristanto, "Simbol-Simbol Liturgi: Studi Tentang Makna Simbol Liturgi Ditinjau Dari Fungsi Pastoral," Jurnal Theologia Aletheia 12, no. 21 (2010): 20-35, http://sttaletheia.ac.id/wp-content/uploads/2012/08/simbolsimbol-liturgi.pdf.

${ }^{36}$ Hasahatan Hutahaean, Bonnarty Steven Silalahi, and Linda Zenita Simanjuntak, "Spiritualitas Pandemik: Tinjauan Fenomenologi Ibadah di Rumah," Evangelikal: Jurnal Teologi Injili dan Pembinaan Warga Jemaat 4, no. 2 (2020): 235-50, https://doi.org/10.46445/ejti.v4i2.270.

${ }^{37}$ James F. White, Pengantar Ibadah Kristen (Jakarta: BPK-Gunung Mulia, 2009), 17-18.
} 
Firman Tuhan di lingkungan orang Yahudi bukan suatu usaha sambilan, melainkan inti dari kegiatan sehari-hari yang merupakan kewajiban. ${ }^{38}$ Tugas dan tanggung jawab mengajarkan Firman Tuhan kepada keluarga merupakan suatu perintah yang harus atau wajib dikerjakan oleh setiap orang tua Kristen seperti yang dikatakan oleh Musa, "Apa yang Kuperintahkan kepadamu hari ini haruslah engkau perhatikan (Ulangan 6:6)". Hal ini menunjukkan bahwa perintah itu harus dilakukan secara aktif dan bukan pasif serta tidak boleh diabaikan. Tanggung jawab mengajarkan Firman Tuhan kepada keluarga harus dilakukan dengan tekun dan tulus oleh seorang kepala keluarga. ${ }^{39}$

Ketiga, Kepala keluarga sebagai penasehat dan teladan. Seorang Kepala keluarga harus mampu menjadi penasehat yang bijaksana bagi keluarganya. Mampu merangkul dan menopang keluarga dalam setiap persoalan dan pergumulan kehidupan secara khusus dalam menghadapi Pandemi Covid-19 yang sedang berlangsung sehingga keluarga tetap mendekatkan diri kepada Allah, taat kepada aturan pemerintah dan gereja dalam menghambat penyebaran Covid-19. Selain itu seorang kepala keluarga harus menjadi teladan rohani yang baik bagi keluarganya. Iman keluarga dapat bertumbuh dengan baik ketika seorang kepala keluarga memiliki contoh yang baik dalam pengaplikasian Firman Tuhan dalam keluarga. Oleh sebab itu, orang tua harus menjadi seorang imam yang mampu memberikan nasihat dan teladan bagi keluarganya. Dalam kitab 1 Timotius 4:12 kata teladan dalam bahasa Yunani

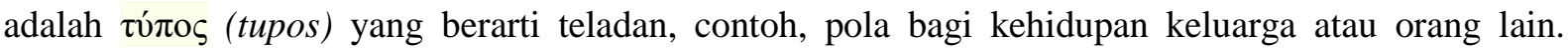
Keteladanan yang Paulus minta adalah teladan dalam perkataan, tingkah laku, kasih, kesetiaan dan kesucian sebagai sarana atau alat untuk mengomunikasikan kasih Allah dan pembentukan moral spiritualitas dalam keluarga. ${ }^{40}$ Dengan demikian nasihat dan keteladanan dari seorang kepala keluarga sebagai imam harus berbanding lurus dengan cara hidupnya sehingga nasihatnya dapat diterima oleh anggota keluarganya.

\section{Eksistensi Keluarga Sebagai Lembaga Transmisi Nilai-Nilai Kekristenan}

Keluarga merupakan tempat pertama untuk mengajarkan dan menaati Firman Tuhan. Perintah, norma serta ketetapan-ketetapan Tuhan diberikan pertama-tama kepada keluarga, baik mulai dari masa penciptaan, pada zaman nabi Nuh, zaman nabi Abraham, dan seterusnya. Selain itu keluarga merupakan tempat Allah bernaung. Apabila kita perhatikan bangsa Israel, mereka mengajarkan ketetapan Tuhan kepada keluarga mereka, yaitu seperti perayaan paskah atau keluarnya orang Israel dari tanah Mesir (Keluaran 12:24-27). Ketaatan terhadap Firman Tuhan (Ulangan 4:9-10), serta pemahaman akan kasih yang terutama kepada Tuhan (Ulangan 6:5-9). ${ }^{41}$

Eksistensi keluarga sebagai lembaga transmisi nilai-nilai kekristenan terlihat dalam kitab Perjanjian Baru tentang pembentukan iman Timotius yang dibentuk di dalam keluarga melalui seorang Lois neneknya dan Eunike ibunya (2 Timotius 1:5). Keluarga ialah "agen" penting dalam mengajarkan nilai-nilai kekristenan. Jadi jangan meremehkan ibadah dan pengajaran-pengajaran Firman Tuhan didalam keluarga. Sebab melalui keluargalah pembentukan iman Kristen dimulai seperti yang di alami oleh Timotius. Sebab dalam Ibrani 10:25 dikatakan "Janganlah kita menjauhkan diri dari pertemuanpertemuan ibadah kita, seperti dibiasakan oleh beberapa orang, tetapi marilah kita saling menasihati, dan semakin giat melakukannya menjelang hari Tuhan yang mendekat”. Ibadah keluarga merupakan persembahan seluruh totalitas kehidupan keluarga kepada Allah yang tak terbatas. Dalam ibadah

\footnotetext{
${ }^{38}$ Asmat Purba, "Tanggung Jawab Orang Tua Kristen Sebagai Pendidik Dalam Menyikapi Dampak Pandemi Covid-19," EPIGRAPHE: Jurnal Teologi dan Pelayanan Kristiani 4, no. 1 (2020): 86-97, http://jurnal.stttorsina.ac.id/index.php/epigraphe/article/view/148/54.

${ }^{39}$ Saragih and Hasugian, "Model Asuhan Keluarga Kristen di Masa Pandemi Covid-19."

${ }^{40}$ Samuel B. Hakh, Berakar Didalam Dia dan Dibangun si Atas Dia (Jakarta: BPK-Gunung Mulia, 2002), $20-21$.

${ }^{41}$ Sokhiziduhu Ndruru, "Pentingnya Pendidikan Agama Kristen Dalam Keluarga Sebagai Sentral Belajar yang Bermisi," Voice of HAMI: Jurnal Teologi dan Pendidikan Agama Kristen 2, no. 1 (2019): 32-44, http://stthami.ac.id/ojs/index.php/hami/article/view/4/3.
} 
keluarga ada suatu perjumpaan antara Allah dengan keluarga serta seluruh anggota keluarga yang bersama-sama berjumpa dengan Allah secara spiritual. Dari uraian di atas cukup jelas menginformasikan kepada kita bahwa peranan kepala keluarga sebagai imam sangatlah penting di tengah-tengah keluarga sebagai lembaga transmisi nilai-nilai kekristenan.

\section{Upaya Penerapan Peranan Kepala Keluarga Sebagai Imam di Tengah-Tengah Keluarga}

Dalam disiplin Gereja Methodist Indonesia (GMI) telah ditetapkan apa-apa saja yang menjadi tugas dan tanggung jawab anggota jemaat, antara lain: (1) Rajin membaca Firman Tuhan setiap hari; (2) Rajin dan tekun berdoa setiap hari; (3) Rajin mengikuti setiap kebaktian, seperti Kebaktian Keluarga, Kebaktian Rumah Tangga, Kebaktian Umum, Kebaktian Evangelisasi, Kebaktian Kebangunan Rohani, dan kebaktian-kebaktian lainnya; (4) Setia mempersembahkan persepuluhan setiap bulan; (5) Setia memberikan persembahan lainnya; (6) Berpartisipasi aktif dalam semua pelayanan di Jemaat GMI. ${ }^{42}$

Tugas dan tanggung jawab anggota jemaat di atas menginstruksikan kesinergian antara ibadah dan kerohanian di tengah-tengah keluarga dengan kerohanian di gereja harus berjalan seimbang. Peranan kepala keluarga sebagai imam jelas tersirat jelas pada poin "kebaktian keluarga" hal ini menginstruksikan bahwa selain kebaktian umum di gereja setiap hari minggu kepala keluarga juga harus berperan sebagai imam di tengah-tengah keluarganya untuk melaksanakan kebaktian atau ibadah keluarga. Selain itu seorang kepala keluarga mampu menuntun keluarganya untuk rajin membaca Firman Tuhan, rajin dan tekun berdoa setiap hari. Setia mempersembahkan persepuluhan setiap bulan dan setia memberikan persembahan lainnya.

Menururt penulis peranan kepala keluarga sebagai imam di tengah-tengah keluarga dapat di bagi dalam beberapa poin, yaitu: (1) mampu menuntun dan memimpin anggota keluarga untuk melaksanakan kebaktian atau ibadah keluarga pada hari minggu; (2) mampu menuntun dan memimpin anggota keluarga untuk melaksanakan kebaktian atau ibadah keluarga pada hari-hari biasa secara singkat; (3) mampu menuntun dan memimpin keluarga untuk rajin membaca Alkitab setiap hari mulai dari kitab Kejadian sampai kitab Wahyu yang dibaca secara bertahap setiap harinya; (4) mampu menuntun dan memimpin keluarga untuk rajin dan tekun berdoa pagi hari sesudah bangun tidur dan pada malam hari sebelum tidur; (5) mampu menjadi penasehat dan teladan yang baik bagi keluarga secara khusus di masa pandemi Covid-19 untuk semakin mendekatkan diri kepada Allah, taat kepada aturan pemerintah dan gereja; (6) memberikan tanggung jawabnya kepada Allah lewat gereja, yaitu persembahan persepuluhan setiap bulan dan persembahan ibadah keluarga setiap minggunya.

Ada sebuah ungkapan dalam tradisi Methodis, yitu "Alkitab ditangan kanan dan disiplin di tangan kiri". Secara sederhana ungkapan itu hendak mengatakan bahwa orang-orang Methodist mencintai Alkitab pertama-tama, kemudian juga harus memahami disiplin gerejanya, sehingga jemaat taat dan disiplin secara rohani kepada Allah. ${ }^{43}$ Dalam kaitan ini, kepala keluarga yang menjalankan peranannya dengan baik sebagai imam di tengah-tengah keluarganya, menunjukkan bahwa mereka menjalankan tugas dan tanggung jawabnya sebagai anggota jemaat GMI Parsambilan secara disiplin sesuai dengan Disiplin GMI. Sebagaimana yang telah penulis uraikan sebelumnya bahwa dalam segi ajaran Alkitab (Kristen) membuat penekanan pada pentingnya keluarga sebagai tempat pelatihan kehidupan sebagaimana iman Timotius dibentuk di dalam keluarga melalui seorang Lois neneknya dan Eunike ibunya (2 Timotius 1:5). Hal ini menunjukkan bahwa kepala keluarga sebagai imam di tengahtengah keluarganya bertanggung jawab menjaga kerohaniannya dan juga keluarganya. Secara tersirat,

$42 \ldots$ _ Disiplin Gereja Methodits Indonesia (Jakarta: Gereja Methodist Indonesia, 2013), 37.

${ }^{43}$ Richard M. Daulay, Episkopal Koneksional: Sejarah, Ajaran, dan Organisasi Gereja Methodist Indonesia (Jakarta: BPK-Gunung Mulia, 2013), 63. 
suami dan istri tidak akan dapat membangun rumah tangga yang baik tanpa didahului takut akan Tuhan, dan secara khusus suami yang takut akan Tuhan mendapat berkat yang luar biasa dari Tuhan.

Peranan kepala keluarga sebagai imam di tengah-tengah keluarganya sangatlah penting untuk terus ditingkatkan sebagai salah satu bukti bahwa anggota keluarga menjalankan tugas dan tanggung jawab mereka dalam hal kedisplinan kerohanian di rumah dan di gereja sebagai anggota jemaat GMI sesuai dengan Disiplin GMI BAB II, Pasal 12. Di sisi lain seorang kepala keluarga bertanggung jawab menjaga kerohanian keluarganya di hadapan Allah yang memberikan keluarga dan yang memberkatinya (1 Tawarikh 17:27; Ulangan 6:6-7, 12:28). Sehingga keluarga Kristen mampu bergumul bersama Yesus Kristus dalam menghadapi pandemi Covid-19, taat pada aturan pemerintah dan gereja dalam menghambat penyebaran Covid-19.

\section{KESIMPULAN}

Dampak Covid-19 yang sedang berlangsung sekarang ini secara khusus membawa dampak terhadap kehidupan kerohanian warga jemaat termasuk di dalamnya bagaimana keluarga Kristen tetap mampu menjaga kualitas kerohaniannya di masa pandemi Covid-19 ini dengan tetap beribadah di rumah. Peranan seorang kepala keluarga sebagai imam di tengah-tengah keluarga sangatlah penting mengingat kepala keluarga berperan menjaga kerohanian keluarganya di hadapan Allah dan gereja-Nya, bahkan kepada semua orang. Fungsi dan peranan utama kepala keluarga sebagai imam ialah menjalankan kebaktian atau ibadah keluarga baik pada hari minggu maupun pada hari-hari biasa; mengajarkan Firman Tuhan kepada keluarga; kepala keluarga mampu menuntun dan memimpin keluarganya untuk rajin membaca Firman Tuhan; mampu menuntun dan memimpin keluarganya untuk rajin dan tekun berdoa setiap hari; mampu menuntun dan memimpin keluarganya untuk setia mempersembahkan persepuluhan setiap bulan; setia memberikan persembahan ibadah keluarga setiap minggunya; mampu menjadi penasehat dan teladan yang baik bagi keluarga secara khusus di masa pandemi Covid-19. Peranan kepala keluarga sebagai imam di tengah-tengah keluarga sangatlah penting untuk terus ditingkatkan sebagai salah satu bukti bahwa anggota keluarga menjalankan tugas dan tanggung jawab mereka dalam hal kedisplinan kerohanian di rumah di masa pandemi Covid-19. Di sisi lain seorang kepala keluarga bertanggung jawab menjaga kerohanian keluarganya di hadapan Allah yang memberikan keluarga dan yang memberkati-Nya. 


\section{DAFTAR PUSTAKA}

. Disiplin Gereja Methodits Indonesia. Jakarta: Gereja Methodist Indonesia, 2013.

Baker, A. Ajaran Iman Katolik. Yogyakarta: Kanisius, 2008.

Baskoro, Paulus Kunto. “Konsep Imam dan Jabatan Imam Pada Masa Intertestamental.” Jurnal Teologi Berita Hidup 3, no. 1 (2020): 81-95. https://www.ejournal.sttberitahidup.ac.id/index.php/jbh/article/view/50/49.

Budiyana, Hardi. "Perspektif Alkitab Terhadap Keluarga Kristen.” Regula Fidei 3, no. 2 (2018): 13745. http://christianeducation.id/e-journal/index.php/regulafidei/article/view/25/24.

Daulay, Richard M. Episkopal Koneksional: Sejarah, Ajaran, dan Organisasi Gereja Methodist Indonesia. Jakarta: BPK-Gunung Mulia, 2013.

Ering, Meilita. "Gereja Rumah di Masa Pandemi Covid-19: Manajemen Resiko dan Mitigasi Bencana Non Alam." Jurnal Sosiologi Agama 1, no. 1 (2020): 1-14. http://ejournal-iaknmanado.ac.id/index.php/putewaya/article/view/214/202.

Gerald O'collins, SJ \& Edward G. Farrugia, SJ. Kamus Teologi. Yogyakarta: Kanisius, 2009.

Gunawan, Agung. "Kasih Fondasi Keluarga Yang Sehat.” Jurnal Theologia Aletheia 21, no. 17 (2019): 59-80. http://sttaletheia.ac.id/e-journal/index.php/solagratia/article/view/95/91.

Hakh, Samuel B. Berakar Didalam Dia dan Dibangun di Atas Dia. Jakarta: BPK-Gunung Mulia, 2002.

Harmadi, Mariani, and Ruat Diana. "Tinjauan Psiko-Teologi Terhadap Fenomena Kekerasan Dalam Pacaran Pada Remaja." Evangelikal: Jurnal Teologi Injili Dan Pembinaan Warga Jemaat 4, no. 1 (2020): 92-102. https://doi.org/10.46445/ejti.v4i1.225.

Homrighausen, E.G dan Enklaar. Pendidikan Agama Kristen. Jakarta: BPK-Gunung Mulia, 2011.

Hutahaean, Hasahatan, Bonnarty Steven Silalahi, and Linda Zenita Simanjuntak. "Spiritualitas Pandemik: Tinjauan Fenomenologi Ibadah Di Rumah." Evangelikal: Jurnal Teologi Injili Dan Pembinaan Warga Jemaat 4, no. 2 (2020): 235-50. https://doi.org/10.46445/ejti.v4i2.270.

Ismail, Andar. Awam dan Pendeta Mitra Membina Gereja. Jakarta: BPK-Gunung Mulia, 2009.

Kridalaksana, H. Kamus Sinonim Bahasa Indonesia. Nusa Indah: Ende, 2009.

Kristanto, Jarot. "Simbol-Simbol Liturgi: Studi Tentang Makna Simbol Liturgi Ditinjau Dari Fungsi Pastoral." Jurnal Theologia Aletheia 12, no. 21 (2010): 20-35. http://sttaletheia.ac.id/wpcontent/uploads/2012/08/simbol-simbol-liturgi.pdf.

Kristianto, Paulus Lilik. Prinsip \& Praktik Pendidikan Agama Kristen: Penuntun Bagi Mahasiswa Teologi \& PAK, Pelayanan Gereja, Guru Agama, dan Keluarga Kristen. Yogyakarta: Andi, 2012.

Leigh, Ronald W. Melayani Dengan Evektif: 34 Prinsip Pelayanan Bagi Pendeta dan Kaum Awam. Jakarta: BPK-Gunung Mulia, 2007.

Mariyanto, Ernest. Kamus Liturgi Sederhana. Yogyakarta: Kanisius, 2008.

Munthe, Bangun. "Peranan Orangtua Terhadap Peningkatan Kesejahteraan Keluarga Untuk Mewujudkan Tanggungjawab Dalam Keluarga, Gereja dan Masyarakat.” Jurnal Agape 1, no. 1 (2018): 62-91. http://repository.uhn.ac.id/handle/123456789/1490.

Ndruru, Sokhiziduhu. "Pentingnya Pendidikan Agama Kristen Dalam Keluarga Sebagai Sentral Belajar Yang Bermisi." Voice of HAMI: Jurnal Teologi dan Pendidikan Agama Kristen 2, no. 1 (2019): 32-44. http://stthami.ac.id/ojs/index.php/hami/article/view/4/3.

Satuan Tugas Penanganan COVID-19. "Ovid-19,” 2020. https://covid19.go.id/.

Pattinama, Claartje. "Peranan Orang Tua Terhadap Perkembangan Pendidikan Anak Dalam Keluarga Kristen." Jurnal Ilmiah Wahana Pendidikan 6, no. 3 (2020): 199-205. https://doi.org/10.5281/zenodo.3951005. 
Poerwadarminta, W.J.S. Kamus Umum Bahasa Indonesia. Jakarta: Balai Pustaka, 2009.

Purba, Asmat. "Tanggung Jawab Orang Tua Kristen Sebagai Pendidik Dalam Menyikapi Dampak Pandemi Covid-19." EPIGRAPHE: Jurnal Teologi dan Pelayanan Kristiani 4, no. 1 (2020): 8697. http://jurnal.stttorsina.ac.id/index.php/epigraphe/article/view/148/54.

Saragih, Albet, and Johanes Waldes Hasugian. "Model Asuhan Keluarga Kristen di Masa Pandemi Covid-19." Jurtnal Teruna Bhakti 3, no. 1 (2020): 1-11. http://stakterunabhakti.ac.id/ejournal/index.php/teruna/article/view/56.

Sembiring, M.K. Pedoman Penafsiran Alkitab Injil Lukas. Jakarta: Lembaga Alkita Indonesia dan Yayasan Karunia Bakti Budaya Idonesia, 2005.

Setiawan, Adib Rifqi. "Lembar Kegiatan Literasi Saintifik Untuk Pembelajaran Jarak Jauh Topik Penyakit Coronavirus 2019 (COVID-19)." Edukatif: Jurnal Ilmu Pendidikan 2, no. 1 (2020): 2837. https://doi.org/10.31004/edukatif.v2i1.80.

Sihombing, Riana Udurman, and Rahel Rati Sarungallo. "Peranan Orang Tua Dalam Mendewasakan Iman Keluarga Kristen.” Journal Kerusso 4, no. 1 (2019): 34-41. https://doi.org/10.33856/kerusso.v4i1.104.

Sijabat, Binsen S. Membesarkan Anak Dengan Kreatif, Panduan Menanamkan Iman\&moral Kepada Anak Sejak Dini. Yogyakarta: Andi, 2013.

“SuratSurat Edaran PGI Nomor: 230/PGI-XVII/2020," n.d.

Tefbana, Abraham, and Djoys Anneke Rantung. "Perspektif Pendidikan Agama Kristen Terhadap Teologi Kebencanaan dan Peran Gereja Dalam Menghadapi Pendemic Covid 19." Jurnal Luxnos 6, no. 1 (2020): 72-88. https://doi.org/10.47304/jl.v6i1.32.

Thompson, Marjorie L. Keluarga Sebagai Pusat Pembentukan: Sebuah Visi Tentang Peranan Keluarga Dalam Pembentukan Rohani. Jakarta: BPK-Gunung Mulia, 2012.

Tindagi, Magdalena G.K. "Indikator Penanaman Nilai-Nilai Pak Dalam Keluarga Bagi Perbinaan Iman Anak Remaja di Zaman Now." Missio Ecclesiae 6, no. 1 (2017): 17-31. https://jurnal.i3batu.ac.id/index.php/me/article/view/67.

Wagiu, Nandari Prastica. "Implementasi Peran Orang Tua Menurut Ulangan 6:4-9 Dalam Pendidikan Agama Kristen Keluarga di Gereja Masehi Injili di Minahasa Jemaat Imanuel Aertembaga Bitung." Jurnal Shanan 4, no. 2 (2020): 128-61. http://ejournal.uki.ac.id/index.php/shan/article/view/1972.

Wakkary, Andriaan MF. "Peran Keluarga Kristen Bagi Pendidikan Remaja." Rhema: Jurnal Teologi Biblika dan Praktika 4, no. 1 (2018): 4-8. https://e-journal.sttyestoya.ac.id/index.php/rhema/article/view/32/21.

White, James F. Pengantar Ibadah Kristen. Jakarta: BPK-Gunung Mulia, 2009. 